Georgetown University Law Center

Scholarship @ GEORGETOWN LAW

2007

\title{
Law as a Tool to Facilitate Healthier Lifestyles and Prevent Obesity
}

Lawrence O. Gostin

Georgetown University Law Center, gostin@law.georgetown.edu

Georgetown Public Law and Legal Theory Research Paper No. 956077

This paper can be downloaded free of charge from:

https://scholarship.law.georgetown.edu/facpub/482

http://ssrn.com/abstract=956077

297 JAMA 87-90 (2007)

This open-access article is brought to you by the Georgetown Law Library. Posted with permission of the author.

Follow this and additional works at: https://scholarship.law.georgetown.edu/facpub

Part of the Health Law and Policy Commons 


\section{Law as a Tool to Facilitate Healthier Lifestyles and Prevent Obesity}

Lawrence O. Gostin, JD

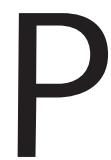

UBLIC HEALTH AGENCIES FACE CONSIDERABLE CHALlenges trying to prevent overweight and obesity in society, primarily because a person's own behavior is often the root cause of the disease. Individuals make personal choices about their diet, exercise, and lifestyle, so disease is often thought of as a matter of personal, not governmental, responsibility.

Obesity, one of the 10 leading US health indicators, ${ }^{1}$ is associated with increased risk of death from type 2 diabetes, hypertension, coronary heart disease, stroke, and certain cancers. ${ }^{2}$ Yet the proportion of overweight and obese children and adults is alarmingly high and continues to increase. In 2005, 60.5\% of adults in the United States were overweight (body mass index, 25-30), 23.9\% were obese (body mass index, 31-40), and 3\% were extremely obese (body mass index $>40$ ). African Americans have the highest obesity prevalence at $33.9 \% .^{3}$ The prevalence of adult obesity increased significantly in every state during the 1990s; therefore, no state will meet the targets for reduced rates of obesity set in Healthy People 2010. ${ }^{4}$ Similarly, 16\% of children and adolescents were overweight, a prevalence that has increased nearly 50\% between 1999 and 2002. ${ }^{5}$ Obesity could shorten the average lifespan of an entire generation by 2 to 5 years, which, if true, would result in the first reversal in life expectancy since data were collected in $1900 .^{6}$

Obesity primarily affects the individual, but it also has high socioeconomic costs. The aggregate consequences of individual choices are countless preventable disabilities and deaths, affecting families and the entire community. Obesityattributable medical expenditures reached $\$ 75$ billion in the United States in 2003, with substantial additional indirect costs in lost productivity. ${ }^{7}$ Critics of state regulation argue that individuals should absorb the cost of their own illness, but taxpayers finance about half of all medical costs through Medicare and Medicaid, and employers cover most of the rest. The government arguably has a legitimate interest in controlling medical and social costs of individuals' unhealthy behaviors that are borne by society at large. Moreover, nonwhite and poor individuals experience substantial disproportionate burdens from obesity, with poor diet and sedentary lifestyles contributing to socioeconomic disparities. ${ }^{8}$
This Commentary discussess how law can be used as a tool to prevent overweight and obesity (TABLE). ${ }^{9}$ The idea has international dimensions, as suggested by the recent adoption of the European Charter on Counteracting Obesity. The charter contains a detailed action plan to improve the availability of healthy foods, promote physical activities, and regulate marketing to children. ${ }^{10}$

\section{Disclosure}

Consumers often eat foods without being aware of the nutritional content or harmful effects. Labels on packaged foods are often obfuscatory, restaurants usually make no disclosures at all, and many consumers are uninformed of the risks from added sodium, fat, and sugar. Government can require companies to disclose the nutritional content of foods and provide health warnings. Canada and the United States, for example, mandate labeling of trans fatty acids on prepackaged foods. ${ }^{11}$ Disclosure rules help consumers make more informed choices, and can benefit the public's health. Disclosure, as a government intervention, is most consistent with prevailing cultural values of consumer autonomy. Thus, informing personal choices rather than restricting them is most likely to find political acceptance.

\section{Tort Liability}

Public health advocates are adapting strategies from tobacco litigation for use in litigation against the food industry. Legal theories range from inadequate disclosure of health risks, misleading advertisements, targeting of children, and deceptive practices, to serving foods that are dangerous beyond the extent ordinarily understood by consumers. In Pelman $v$ McDonald's, the court gave hope to advocates when it permitted plaintiffs' claims alleging deceptive representation of the nutritional benefits of McDonald's food to go to trial. ${ }^{12}$ But beyond this case, food litigation has been largely unsuccessful and politically unpopular. Currently, 21 states have "commonsense consumption" or "personal responsibility" laws that sharply limit tort liability. ${ }^{13}$

Author Affiliation: O'Neill Institute for National and Global Health Law, Georgetown University Law Center, Washington, DC; and Department of Health Policy and Management, Johns Hopkins Bloomberg School of Public Health, Baltimore, Md.

Corresponding Author: Lawrence O. Gostin, JD, Georgetown University Law Center, 600 New Jersey Ave NW, Washington, DC 20001 (gostin@law.georgetown .edu). 


\section{Surveillance}

Infectious disease surveillance is well accepted, but the idea that the state should monitor chronic diseases is contested. ${ }^{14}$ New York City has adopted a diabetes surveillance program including mandatory laboratory reporting of glycated hemoglobin, recommendations for physicians to manage patients with poor glycemic control, and provision of advice to patients about diabetes management. The goals are to improve patient monitoring and provide feedback and support to physicians and patients. ${ }^{15}$

The close involvement of public health officials in clinical practice and patient adherence represents a new way of thinking about surveillance and follow-up to track and manage chronic diseases. But civil libertarians and physicians vehemently oppose surveillance, believing it interferes with personal autonomy and privacy, as well as clinical freedom. Patients can opt out of receiving health department advice, but not the reporting requirement However, opting out is a complex procedure and it requires limited information disclosure..$^{15}$ Physicians also claim that the program interferes with the therapeutic relationship. A key question is whether aggressive surveillance and case management of a disease with a substantial negative effect on the public's health offers sufficient benefits to offset the limited invasion of patient privacy and clinical freedom.

\section{Targeting Children and Adolescents}

The food industry spends more than $\$ 11$ billion annually on advertising to children and adolescents, and often uses innovative methods, such as Internet advertising, Internet "advergames," and product placements on popular television shows. ${ }^{16}$ America's youth is exposed to approximately 40000 food advertisements annually, the vast majority of

\begin{tabular}{|c|c|c|c|c|}
\hline Intervention & Definition & Public Health Benefits & Arguments in Favor & Arguments Against \\
\hline $\begin{array}{l}\text { Disclosure } \\
\text { (eg, nutritional } \\
\text { labeling) }\end{array}$ & $\begin{array}{l}\text { Requires food } \\
\text { manufacturers and } \\
\text { restaurants to disclose } \\
\text { nutritional contents }\end{array}$ & $\begin{array}{l}\text { Informs consumers about } \\
\text { the nutritional benefits } \\
\text { and risks }\end{array}$ & $\begin{array}{l}\text { Nutritional information can allow } \\
\text { consumers to make more } \\
\text { informed choices } \\
\text { May inform consumers who } \\
\text { are unaware of dangers } \\
\text { of fast food }\end{array}$ & $\begin{array}{l}\text { Difficult to provide accurate } \\
\text { information particularly } \\
\text { from restaurants that } \\
\text { change menus } \\
\text { Food labels often misleading } \\
\text { and inconsistent }\end{array}$ \\
\hline Tort liability & $\begin{array}{l}\text { Litigate against deceptive } \\
\text { practices, false claims, } \\
\text { and unreasonably } \\
\text { hazardous products }\end{array}$ & $\begin{array}{l}\text { Forces fast food companies } \\
\text { to offer healthier } \\
\text { alternatives and give } \\
\text { accurate information } \\
\text { Prevents targeting } \\
\text { of children }\end{array}$ & $\begin{array}{l}\text { Discovery may uncover } \\
\quad \text { deception } \\
\text { May change public opinion } \\
\text { May alter business practices }\end{array}$ & $\begin{array}{l}\text { Against public opinion } \\
\text { Hard to prove fast food } \\
\text { consumption causes } \\
\text { disease given confounding } \\
\text { variables }\end{array}$ \\
\hline $\begin{array}{l}\text { Surveillance } \\
\text { (eg, diabetes } \\
\text { surveillance) }\end{array}$ & $\begin{array}{l}\text { Provide data for monitoring } \\
\text { population health, } \\
\text { feedback, action alerts, } \\
\text { and clinical } \\
\text { recommendations }\end{array}$ & $\begin{array}{l}\text { Improves diabetes } \\
\text { epidemiology } \\
\text { Provides individual and } \\
\text { aggregate feedback } \\
\text { and support }\end{array}$ & $\begin{array}{l}\text { May help the majority of } \\
\text { patients who do not know } \\
\text { their glycated hemoglobin } \\
\text { values and do not } \\
\text { adequately manage } \\
\text { the disease }\end{array}$ & $\begin{array}{l}\text { Impinges on clinical autonomy } \\
\text { and therapeutic relationship } \\
\text { Reporting is time consuming } \\
\text { Informed consent and } \\
\text { confidentiality would be } \\
\text { necessary }\end{array}$ \\
\hline $\begin{array}{l}\text { Regulation of food } \\
\text { marketing to } \\
\text { children and } \\
\text { adolescents }\end{array}$ & $\begin{array}{l}\text { Regulate media, Web, } \\
\text { advergames, character } \\
\text { licensing, and stealth } \\
\text { marketing }\end{array}$ & $\begin{array}{l}\text { Helps control the influences } \\
\text { of advertising on eating } \\
\text { habits and purchasing } \\
\text { patterns }\end{array}$ & $\begin{array}{l}\text { May help prevent deceptive and } \\
\text { misleading advertisements } \\
\text { May help protect children } \\
\text { (less capable of making } \\
\text { distinctions) }\end{array}$ & $\begin{array}{l}\text { Impinges on freedom of } \\
\text { commercial speech } \\
\text { Paternalistic }\end{array}$ \\
\hline Taxation & $\begin{array}{l}\text { Impose higher taxes on } \\
\text { calorie-dense, } \\
\text { nutrient-poor foods }\end{array}$ & $\begin{array}{l}\text { Lowers consumption of } \\
\text { unhealthy foods } \\
\text { Generates revenue to } \\
\text { subsidize healthful foods } \\
\text { and physical activity }\end{array}$ & $\begin{array}{l}\text { Other countries use fiscal } \\
\text { measures to influence diet } \\
\text { Effective; compare with taxes } \\
\text { on alcohol and tobacco use }\end{array}$ & $\begin{array}{l}\text { Regressive tax } \\
\text { Freedom of choice } \\
\text { Tax revenues are often used } \\
\text { to cover budget deficits } \\
\text { No consistency on which foods } \\
\text { to tax }\end{array}$ \\
\hline $\begin{array}{l}\text { School and } \\
\text { workplace } \\
\text { policies }\end{array}$ & $\begin{array}{l}\text { Remove vending machines } \\
\text { and provide healthier } \\
\text { menus, more physical } \\
\text { activity, and } \\
\text { nutritional/physical } \\
\text { education }\end{array}$ & $\begin{array}{l}\text { Reduces high calorie } \\
\text { temptations } \\
\text { Provides more opportunity } \\
\quad \text { for exercise } \\
\text { Enhances learning }\end{array}$ & $\begin{array}{l}\text { May influence nutrition } \\
\text { and physical activity } \\
\text { and help establish healthful } \\
\text { eating habits } \\
\text { May prevent undue influences } \\
\text { on young people }\end{array}$ & $\begin{array}{l}\text { Difficult to implement } \\
\text { Resource intensive } \\
\text { Inefficient if dietary habits } \\
\quad \text { do not change at home }\end{array}$ \\
\hline $\begin{array}{l}\text { The "built" } \\
\text { environment: } \\
\text { zoning }\end{array}$ & $\begin{array}{l}\text { Enact zoning laws to limit } \\
\text { prevalence of fast foods, } \\
\text { expand recreational } \\
\text { opportunities, and } \\
\text { encourage healthier } \\
\text { lifestyles }\end{array}$ & $\begin{array}{l}\text { Gives individuals greater } \\
\text { choice and opportunity } \\
\text { to eat healthy foods, } \\
\text { recreate, and exercise, } \\
\text { especially in poor } \\
\text { neighborhoods }\end{array}$ & $\begin{array}{l}\text { Fast food chains drive out } \\
\text { healthier alternatives } \\
\text { Governments often use zoning } \\
\text { powers to restrict business } \\
\text { Access to healthier foods }\end{array}$ & $\begin{array}{l}\text { Access to healthier food alone } \\
\text { will not prevent overeating } \\
\text { Slippery slope to an outright } \\
\text { ban of fast food } \\
\text { Restricts competition }\end{array}$ \\
\hline $\begin{array}{l}\text { Food prohibitions } \\
\text { (eg, trans fat ban) }\end{array}$ & $\begin{array}{l}\text { Require companies to } \\
\text { remove certain } \\
\text { ingredients that pose } \\
\text { health hazards }\end{array}$ & $\begin{array}{l}\text { Reduces certain hazardous } \\
\text { ingredients from the } \\
\text { food supply }\end{array}$ & $\begin{array}{l}\text { Improved diets as consumers } \\
\text { avoid hazardous ingredients } \\
\text { Consumers may not be able to } \\
\text { discern difference in taste }\end{array}$ & $\begin{array}{l}\text { Causes expense for food } \\
\text { industry to make the switch } \\
\text { Constitutes restriction on trade } \\
\text { Affects freedom of choice }\end{array}$ \\
\hline
\end{tabular}


which are for candy, cereal, and fast foods. ${ }^{9}$ Studies suggest that advertising can significantly shape the eating habits of young people, and the purchasing patterns of their parents. ${ }^{16}$ Young children, moreover, are unable to understand the persuasive intent of advertising or to view it critically. ${ }^{16}$ Consequently, regulatory strategies include restricting food advertising during children's programs, counteradvertising to promote good nutrition and physical activity, limiting the use of cartoon characters, and restricting Web-based games and promotions.

Regulating the content of food advertising is contentious, with constitutional overtones. Certainly, the public supports, and the US Constitution permits, regulation of misleading messages directed toward young people. However, there is no consensus on what messages are misleading or simply alluring. Moreover, adults as well as children see most media outlets. Despite First Amendment concerns, regulation of advertising to children may be politically acceptable given the potential for manipulation of vulnerable youth and the state's responsibility to protect minors.

\section{Taxation of Unhealthy Food}

Public health advocates believe that food costs are out of balance, with healthy foods costing more than unhealthy ones. Some have proposed a "fat tax" as a proactive response to a food industry and consumer culture that increasingly promote unhealthy foods as the cheapest, tastiest, and most available dietary options ${ }^{17}$ Colloquially known as a "junk food," snack, or "Twinkie tax," the levy would provide a disincentive for purchasing caloriedense, nutrient-poor foods. The tax revenue could also be used to promote healthy nutrition and anti-obesity programs. For example, a national tax of $1 \$$ per 12 -oz soft drink would generate an estimated $\$ 1.5$ billion annually, and similar revenues could be generated with taxation of candy, chips, and other snack foods. ${ }^{17}$ The World Health Organization has lent its support, noting that food purchasing patterns could be influenced through taxes and subsidies. ${ }^{18}$

Critics are stridently opposed to taxation of foods, particularly those most desired by consumers. ${ }^{14} \mathrm{~A}$ fat tax is thought to be paternalistic and regressive because poor people are the primary consumers of high-fat foods. But most of all, critics wonder how it is possible to decide which foods should be taxed and why. Food is not like tobacco, which is never beneficial. People need food to survive, and any food may be acceptable when eaten in moderation.

\section{School Policies}

The food industry has inserted its foods and brand images in public schools throughout the United States. To obtain badly needed funds, schools allow food companies to sell their products and advertise on school property. Even meals served under the National School Lunch Program contain fat and calories exceeding federal guidelines. ${ }^{19}$ Only

@2007 American Medical Association. All rights reserved. a minority of schools requires daily physical education classes. But government can require schools to adhere to dietary guidelines and portion size for snacks and school lunches, or even ban certain foods from vending machines, shops, and cafeterias. Indeed, several companies have voluntarily removed unhealthy beverages and snack foods from schools. ${ }^{20}$ At the same time, schools can increase opportunities for nutrition education and physical activities.

These policies should be uncontroversial because they involve the health of children who are forming lifetime habits and are not in a position to fully discern the risks and potential dangers. Yet, many believe that diet and physical activity are the responsibility of parents, and school policies may be ineffective if children's dietary habits do not change at home.

\section{The Built Environment}

The environment in many poor, nonwhite neighborhoods is not conducive to healthy living, with limited access to nutritional foods, recreational facilities, and safe places for walking and playing. ${ }^{21}$ Consequently, government could facilitate healthier eating and exercise patterns by altering the "built environment"- manmade structures that constitute individuals' living spaces. Local officials could limit the number of fast food restaurants, build recreational parks and bike paths, expand mass transportation, and provide incentives to stores that sell nutritious and affordable foods. Many communities, for example, have zoning restrictions on fast food outlets, including wholesale prohibitions, limited bans on "formula" restaurants (fast food chains with standardized menus, name, and appearance), and quotas on the number of restaurants. ${ }^{22}$

Land use for public health purposes used to be a wellaccepted practice in local government, but is controversial today. ${ }^{23}$ Critics believe that government officials should not impose their values on the public, and that buying and selling food should be part of a free marketplace. But, there are undoubted social, economic, and physical influences on eating habits, and government could strive to make healthier foods an easier choice for the public.

\section{Food Prohibitions}

Perhaps the most coercive and politically divisive form of obesity regulation is an outright ban on foods or ingredients deemed to be particularly harmful. A growing body of scientific evidence links trans fatty acids to coronary heart disease. The Institute of Medicine concluded there is no safe level of trans fat consumption and that it provides no known benefit to human health. ${ }^{24}$ In 2003, Denmark became the first country to set an upper limit on the percentage of industrially produced trans fat in foods. New York City recently restricted the service of products containing artificial trans fat in all food service establishments. As of July 1 , 2007 , restaurants will be prohibited from preparing reci-

(Reprinted) JAMA, January 3, 2007—Vol 297, No. 189 
pes that contain more than $0.5 \mathrm{~g}$ of trans fat per serving. ${ }^{25}$ Supporters believe that eliminating a known health risk from foods will decrease morbidity and premature mortality in the population.

The fierce debates about the propriety of a ban on trans fat focus on scientific credibility and cost-effectiveness. At one time, the government actively promoted refined oil products high in trans fat, even encouraging low-income populations to choose margarine over butter. A key question today is whether there is sufficiently robust evidence that trans fat is more dangerous than saturated fat to justify new public policies. In light of experience with apparently contradictory government health messages, the public may doubt the credibility of current pronouncements. Moreover, a trans fat ban could drive the market back toward saturated fats.

The food industry asserts that government prohibitions undermine competitive markets and free trade. Removing trans fat from foods is expensive and they believe it affects the food's taste and desirability. Local bans can have potentially far-reaching impacts on interstate and foreign commerce, with a ban in one city affecting operations everywhere. The strongest objection to a trans fat ban is that it is paternalistic. Critics argue that people are capable of deciding what to eat, and making the tradeoffs between taste, current pleasures, and future health consequences.

Despite the undoubted political risks, should public health agencies push for strong measures to control obesity, perhaps even banning hazardous foods? The justification lies with the epidemic rates of overweight and obesity, the preventable morbidity and mortality, and the stark health disparities based on race and socioeconomic status. If the problem were related to pathogens, tobacco, or lead paint, most would support aggressive measures to protect innocent individuals from hazards created by others. But comfort foods also have hidden hazards-it is difficult to tell if they are laden with fat and, if so, what kind. Although the public dislikes paternalism, it is at least worth considering whether such an approach is ever justified to regulate harms that are apparently self-imposed, but also are deeply socially embedded and pervasively harmful to the public.

Financial Disclosures: None reported.

\section{REFERENCES}

1. US Department of Health and Human Services. Healthy People 2010. Washington, DC: Dept of Health and Human Services; 2000.

2. Adams KF, Schatzkin A, Harris TB, et al. Overweight, obesity, and mortality in a large prospective cohort of persons 50 to 71 years old. N Eng/ J Med. 2006;355: 763-778.

3. Centers for Disease Control and Prevention. State-specific prevalence of obesity among adults-United States, 2005. MMWR Morb Mortal Wkly Rep. 2006; 55:985-988.

4. Trust for America's Health. $F$ as in Fat: How Obesity Policies Are Failing in America. Washington, DC: Trust for America's Health; 2004

5. Hedley AA, Ogden $\mathrm{CL}$, Johnson $\mathrm{CL}$, et al. Overweight and obesity among US children, adolescents, and adults, 1999-2002. JAMA. 2004;291:2847-2850.

6. Olshansky SJ, Passaro DJ, Hershow RC, et al. A potential decline in life expectancy in the United States in the 21st century. N Eng/ J Med. 2005;352:1138-1145.

7. Finkelstein EA, Fiebelkorn IC, Wang G. State-level estimates of annual medical expenditures attributable to obesity. Obes Res. 2004;12:18-24.

8. Chang VW, Lauderdale DS. Income disparities in body mass index and obesity in the United States, 1971-2002. Arch Intern Med. 2005;165:2122-2128.

9. Mello MM, Studdert DM, Brennan TA. Obesity - the new frontier of public health law. N Engl J Med. 2006;354:2601-2609.

10. World Health Organization Regional Office for Europe. European charter on counteracting obesity. http://www.euro.who.int/Document/E89567.pdf. Accessed December 6, 2006.

11. Health Canada Web site. TRANSforming the food supply. http://www.hc-sc .gc.ca/fn-an/nutrition/gras-trans-fats/tf-ge/tf-gt_rep-rap_e.html. Accessed November 20, 2006

12. Pelman v McDonald's, 396 F3d 508 (2005).

13. National Restaurant Association Web site. State frivolous-lawsuit legislation. http://www.restaurant.org/government/state/nutrition/bills_lawsuits.cfm. Accessed November 20, 2006.

14. Epstein R. What (not) to do about obesity: a moderate Aristotelian answer. Georgetown Law J. 2005;93:1361-1386.

15. Frieden TR. Asleep at the switch: local public health and chronic diseases. Am J Public Health. 2004;94:2059-2061.

16. Institute of Medicine. Food Marketing to Children and Youth: Threat or Opportunity? Washington, DC: National Academies Press; 2006.

17. Jacobson MF, Brownell KD. Small taxes on soft drinks and snack foods to promote health. Am J Public Health. 2000;90:854-857.

18. World Health Organization Web site. Frequently asked questions about the WHO global strategy on diet, physical activity and health. http://www.who.int /dietphysicalactivity/faq/en/index.html. Accessed November 20, 2006.

19. US Government Accounting Office. School Lunch Program: Efforts Needed to Improve Nutrition and Encourage Healthy Eating. Washington, DC: US Government Accounting Office; 2003:GAO-03-506.

20. Burros M. Producers agree to send healthier foods to school. New York Times. October 7, 2006.

21. Block JP, Scribner RA, DeSalvo KB. Fast food, race/ethnicity, and income: a geographic analysis. Am J Prev Med. 2004;27:211-217.

22. Mair JS, Pierce MW, Teret SP; The Center for the Law \& the Public's Health Web site. The use of zoning to restrict fast food outlets: a potential strategy to combat obesity, October 2005. http://www. publichealthlaw.net/Zoning\%20Fast \%20Food\%20Outlets.pdf. Accessed December 6, 2006.

23. Perdue WC, Stone LA, Gostin LO. The built environment and its relationship to the public's health: the legal framework. Am J Public Health. 2003;93:1390-1394. 24. Institute of Medicine. Dietary Reference Intakes for Energy, Carbohydrate, Fiber, Fat, Fatty Acids, Cholesterol, Protein, and Amino Acids. Washington, DC: National Academies Press; 2005.

25. New York City Department of Health and Mental Hygiene Board of Health. Notice of adoption of an amendment (\$81.08) to article 81 of the New York City Health Code. http://www.nyc.gov/html/doh/downloads/pdf/public /notice-adoption-hc-art81-08.pdf. Accessed December 6, 2006. 